\title{
Procurement Reforms in Africa: The Strides, Challenges, and Improvement Opportunities
}

\author{
Mawuko Dza ${ }^{1}$, Ron Fisher ${ }^{1} \& \operatorname{Rod}_{\text {Gapp }}{ }^{1}$ \\ ${ }^{1}$ Griffith University, Gold Coast Campus, Australia \\ Correspondence: Mawuko Dza, Griffith University, Gold Coast Campus, Queensland 4222, Australia. Tel: \\ 6-175-552-9272. E-mail: dzama2010@gmail.com
}

Received: May 27, 2013 Accepted: June 17, 2013 Online Published: September 29, 2013

doi:10.5539/par.v2n2p49 URL: http://dx.doi.org/10.5539/par.v2n2p49

\begin{abstract}
Procurement reforms are seen as essential for achieving a long term improvement in financial management within Africa. To gain insight into this situation an analysis of success stories and cases where challenges and difficulties have arisen were investigated. This material was content analysed using Mayring (2008) four-step process model. The findings demonstrate some initial improvement within African public sector financial management; however the complete and successful implementation of these reforms is fraught with problems. These issues that limit improved financial management through procurement reform included; inadequate education and training, legislative constraints, especially those associated with procurement technology, and a lack of political support for the reform process. In political terms the study identified that the current political position coupled with socio-cultural sensitivities of participating countries, has created a neglect of ethical and environmental considerations which in turn has slowed the pace and acceptance of reforms.
\end{abstract}

Keywords: Africa, content analysis, socio-cultural, political will, procurement, reforms, technology transfer, transparency

\section{Introduction}

Most governments in Africa have instituted reforms in public procurement. The major goals of these reforms are to encourage competition, improve financial transparency, and ensure accountability in public institutions (Hunja, 2003). Procurement reforms in Africa have to some extent brought modernity, transparency, competition, as well as fairness in the procurement process. Notwithstanding the improved administrative and structural systems put in place to enhance efficiency in public procurements, these reforms have not gone without blemish. Indeed, the implementation of procurement reforms in Africa has been fraught with cultural insensitivity, the disregard for countries' political, socio-economic, ethical, and environmental structures and systems. The result is the lack of interest and political will to confront the challenges of the reform leading to haphazard and lacklustre approach towards its implementation (Hunja, 2003).

It is significant to acknowledge that, because the procurement function did not establish itself within the academic ranks and research institutions until recent years, a search of contemporary literature on the subject shows little evidence that public procurement has penetrated the theoretical boundaries of academic research, despite the profession's efforts over a decade to enhance, develop, and improve its profile in the eye of other professions (Matthews, 2005). Notwithstanding its theoretical limitations, the international trade centre (ITC) recognising the value of the procurement function, explains that, its experience in developing countries shows that public procurement may be contributing between 50-70 per cent of imports in these countries. Implicitly, improvements in public procurement systems in developing countries could have a direct and beneficial effect on the overall economic situation of the countries. Evaluating the benefits developing countries could derive from well structured procurement systems necessitated intervention programs from the World Bank and other regional institutions like the African Development Bank (AfDB) to assist developing countries to review and revise their procurement structures and systems (Wittig, 1999).

African countries have various reasons for wanting to undertake procurement reforms. Some countries undertake reforms to support essential internal administrative improvements, others accept reform programs to help qualify for international financing from multilateral institutions, or to help integrate a country into the multilateral trading system. Procurement reforms are often seen as an important feature of anti-corruption efforts that can help promote 
good governance (Thai, 2008). Transparency in public procurement is an important issue for all countries. Developed countries have established various means to create and sustain transparency. It has become imperative for African governments to incorporate monitoring and control systems into public procurement to consolidate the modest gains especially in areas of transparency, equity and fairness in their current structures (Wittig, 1999). In recent years, the impetus for reforms have increased, partly in consequence of requirements set by the World Bank and other donor organisations as a condition for providing development aid, but principally because the inefficiencies of unreformed systems have become self-evident. Most donors consider that a well functioning procurement system is an essential requirement if their funds are able to be used effectively to promote development (Abeille, 2003). In most African countries the aim of accepting and instituting these reform programs is to establish a strong and well-functioning procurement system that is governed by a clear legal framework establishing rules for transparency, efficiency and mechanisms of enforcement, coupled with an institutional arrangement that ensures consistency in overall policy formulation and implementation (Hunja, 2003). This paper analyses gains countries have made as a consequence of introducing these reforms. Major challenges impinging on the smooth implementation of the reforms are also examined. The paper finally gives some insights into improvement strategies of implementing procurement reforms.

\section{Method}

The paper adopted content analysis approach because it represents an effective tool for analysing samples of research documents in a systematic and rule-governed manner (Seuring \& Gold, 2012). Seuring and Gold (2012) argue that, content analysis is most suitable and appropriate for analysing published materials and was thus deemed as a suitable approach for this research. In conducting a systematic review of literature, the authors followed the process model of material collection, descriptive analysis, category selection, and material evaluation (Mayring, 2008). Addressing the process model, material for analysis were delimited and the unit of analysis defined; the characteristics of the material were thoroughly assessed; the structural dimensions and related analytical categories were developed and selected, after which the text material was evaluated. To assure trustworthiness of our research findings a multiple researcher approach was followed. The use of multiple researchers in identifying latent content ensured that judgements were shared by all members of the research team thereby enhancing the trustworthiness of the findings.

\section{The Imperative for Procurement Reforms}

The significant contributions the procurement function makes to organisations and national economies makes it imperative to put in place formal administrative and legal frameworks to ensure that due process is followed in the execution and implementation of procurement policies. Reporting on the contributions of the procurement function to various sectors of economies, Leenders, et al., (2006) indicate that, for a manufacturing firm, a 10 per cent improvement in procurement and supply costs are equivalent to profit resulting from 75 per cent increase in sales. The ADB/OECD (2008) estimate that, public procurement accounts for about 20 per cent of government expenditure worldwide. Across Africa, government procurement averages around 10 per cent of GDP and can account for up to 70 percent of public expenditure, as in the case of Tanzania and Uganda (Woolcock, 2008). In Botswana, public procurement exceeded $\$ 1$ billion in 2003 (Lionjanga, 2003). In Ghana, about 43.8 per cent of the national budget is spent on public procurement, and a further 90 per cent of all development partners inflows are spent through procurement related activities (World Bank, 2003). Government expenditure on public procurement in South Africa accounts for 13 per cent of GDP or $\$ 14$ billion in 2003 . There is also an additional $\$ 5$ billion in procurement by state owned enterprises, making 17 per cent of GDP in total (Woolcock, 2008).

In developed economies, the procurement functions' contributions to GDP cannot be over-emphasised. In the European Union, public procurement accounts for 16 per cent of GDP (Mathew, 2010). It is also estimated that the public sector in the UK spends $£ 150$ billion a year on goods and services necessary to deliver public services (European Commission, 2007). According to the Australia Procurement and Construction ouncil (APCC) the value of procuring capital assets, maintenance, goods and services by the federal government now exceeds AUD $\$ 100$ billion dollars per year (APCC, 2008). The APCC argues that if one per cent each across board savings is made through effective and efficient procurement in these areas, the federal government could be saving about one billion dollars per year on procurement. The APCC recognises procurement as a strategic cost-management function for which it is necessary to maintain high-level leadership to plan effectively, source innovatively to actively manage contracts and to continuously improve processes. The APCC suggests that because governments' annual aggregated procurement spend is approximately AUD \$214 billion dollars, constituting about 20 per cent of Australia's GDP, it is necessary to invest in sustainable reforms in order to continuously improve upon procurement processes, procedures, and practices (Scott, 2008). 


\section{Procurement Reforms in Africa}

Public procurement is a major function of governments, and governmental entities, and this has been recognised by most African governments. This recognition has led to the institution of reforms in these countries public procurement processes aimed at encouraging competition, transparency, efficiency and ensuring accountability (Hunja, 2003). Prior to the institution of reforms, many African governments' procurement was based on systems inherited from the colonial era in which procurement was regulated by ministerial directives rather than a comprehensive procurement code. This often resulted in fragmentation and complexity in procurement decision making. As the old systems became progressively weaker and uncontrollable it provided scope for abuse and inefficiencies (Hunja, 2003). Since the international conference on reforms of public procurement in Africa held in Abidjan in 1998, the African development bank group (AfDB) has been assisting member countries in reforming their national procurement systems. In line with its commitments under the Paris Declaration, the AfDB has been working together with other development partners in establishing tools and strategies to move towards the use of country systems regarding procurement. Assisting African governments to modernise and strengthen their public procurement systems at both regional and national levels, it is believed will open the way for development partners to use country procurement systems, which will facilitate the implementation of projects and improve overall public financial management capacity of implementing countries (AfDB, 2012). The aftermath of the Abidjan conference saw several African countries embark on procurement reform programs with the support of the AfDB, the World Bank and other development partners, and the assistance of sub-regional organisations such as the Common Market for Eastern and Southern Africa (COMESA), the West African Economic and Monetary Union (WAEMU), which have adopted regional directives on public procurement (AfDB, 2009).

Public procurement reforms among African countries are not significantly different in terms of stages of reform, components of reform strategies, and implementation. In most African countries, public procurement reforms have been preceded by assessments of the existing system, either by consultants or by external donor agencies particularly the World Bank through country procurement reports. Such studies made recommendations to governments based on which reforms of public procurement have been modelled. In terms of components of the reforms, most African countries have created new procurement legislations that have put in place new institutional frameworks through which procurement is expected to be managed. Every country that has attempted to reform its public procurement system, have instituted control measures like a central authority where procurement activities are coordinated to ensure that systematic processes are followed (Thai, 2008).

\section{The Strides}

In the past two decades, African countries have undertaken a number of reforms of their public financial management, particularly its procurement systems. The reform programs has provided comprehensive administrative and legal framework for public procurement. New institutions such as the public procurement authority and the appeals and complaints panel have been set up to formalise and improve procurement performance (Honkaniemi, 2010). In accordance with Ghana's public procurement law, the procurement process must allow suppliers, contractors and consultants to compete for business on a fair basis. Public officials associated with the procurement function, therefore are responsible for protecting the integrity of the procurement process and maintaining fairness in government's treatment of all suppliers, contractors and consultants. The law further stipulates that, correspondence and communications are essential to the management of relationships with suppliers and other stakeholders (Public Procurement Act of Ghana, 2003).

Most African countries have made incredible efforts at reforming their public procurement regulations and practices. In countries like Ghana, Uganda, and Kenya, the reforms have not been limited to regulations alone, they have included public procurement processes, methods, procurement organisational structure, and even the workforce (Ameyaw, Mensah, \& Ameyaw, 2011). Currently most governments in Africa have come to the realisation that a well organised procurement system contributes to good governance by increasing public confidence and assuring judicious government spend (Ahuja, 2000). Indeed, African governments have accepted the fact that increasing the efficiency and transparency in the use of public funds requires the existence of an adequate national procurement system that meets both national and international standards and operates efficiently (Ameyaw et al., 2011). A well-functioning procurement system is the one that is governed by a clear legal framework establishing the rules for transparency, efficiency and mechanisms of enforcement, coupled with an institutional arrangement that assures consistency in overall policy formulation and implementation (Hunja, 2003).

Training and education of procurement practitioners is instrumental to the success of public procurement reforms. Over the years, the issue of acquiring well-trained professionals with requisite experience and competence has 
been a major bane of the reforms. However, the situation seem to be gradually improving as an assessment in 2009/2010 on the expertise of practitioners revealed that some efforts has being made in partly addressing the skill shortage and expertise problem. The OECD/DAC (2011), report that some countries have implemented a comprehensive short-term training program which resulted in the training of quite a substantial numbers of practitioners. The courses were specifically targeted at procurement practitioners, members of tender committees and tender review boards, private sector representatives, and staff of oversight institutions. With support from donor grants, specialised contract management courses were also offered. Despite efforts by developmental agencies at offering training and education to practitioners in Africa, the training programs have been criticised of lacking local content thus ignoring issues pertaining to culture, socio-economic, and political sensitivities.

\section{The Challenges}

In the face of mounting economic uncertainty, huge expectations are placed on procurement practitioners to source the best business solutions from their supply network partners, and to achieve the innovation, value and services that their customers are looking for (Lau, 2010). It is also acknowledged that the success of an organisation largely depends on its human capital, which refers to the collective knowledge, experience, skills and abilities of staff (Maister, 1986). As procurement moves towards being a tactical and strategic function, it has become imperative that staff development through training take centre stage in the developmental process (Humphreys et al., 1998). More importantly, with the call for the incorporation of technology into procurement processes, there is no doubt that its successful adoption requires practitioners to enhance their expertise in fields such as, business processing re-engineering, IT training and organisational change, all of which hinge on effective and efficient education and training. Thus, in order to achieve a more strategic and collaborative supply network, practitioners require additional training and education (Lau, 2010). Research has shown that practitioners with high skills levels and knowledge have significant impact on financial performance and operational efficiency in terms of quality improvement, design and reduction of lead times (Cousin et al., 2006). The other aspect in which developing countries are reforming the way in which procurement is carried out is by bringing professionalism to those who carry out and manage the procurement function. Raising the strategic profile of procurement by making it core to good service delivery necessitates the formation of a professional cadre of public officials to implement this function. Instituting ongoing training programs and having a scheme within the public service that enables procurement professionals to gain seniority commensurate to their expertise and experience have been the cornerstones of reforms in this area (Hunja, 2003).

An assessment of Ghana's procurement system in 2007 by the OECD/DAC although confirming substantial progress in public procurement since 2003, also alluded to the fact that some provisions in the Public Procurement Act have proven to be ineffectual and require adjustments or modifications. These include, incorrect interpretation and application of some provisions of the procurement law, slow pace in regularising draft regulations, lack of clear procedures for emergency procurement, lack of training avenues for practitioners, poor record management, poor handling of suppliers' complaints, poor procurement planning, poor contract management and high cost of advertisement. According to the report these challenges cut across most African countries (OECD/DAC, 2011). The report further indicates that no sustainable procurement training programs are put in place for practitioners to access. Key stakeholders such as the private sector and audit institutions also lack procurement expertise (OECD/DAC, 2011).

Many independent research findings (e.g., Odhiambo \& Kamau, 2003; Araujo, 2004; Doyle, 2006) have argued that formalising the professionalism of procurement capability is inextricably linked to raising the profile and credibility of procurement practice and promoting the development of a common and transferable body of knowledge. This call for the expansion and formalisation of procurement training has been suggested in successive UN General Assembly resolutions on procurement reforms since the mid 1990s (United Nations General Assembly, 2007). For example, in resolution 51/231 of June 131997 (paragraph 31), the Assembly urged the Secretary-General to intensify training programs in procurement for all member countries (World Bank, 2003). Responding to the clarion call, numerous attempts have been made to develop and implement a standardised framework of procurement competencies that will facilitate the design and possible adoption of procurement systems as applied in developed countries to emerging economies like Africa (Hsu, 2009; Kung \& Gordon, 2007). Crucially, framework models in developed countries are based on national cultural, social, ethical, economic, political, and other environmental considerations which may not necessarily address specific procurement needs in African countries (Hsu, 2009; Helgadottir, 2008).

Another major challenge of current procurement reforms in Africa is the programs' opposition towards relational exchanges with key suppliers. The lack of these exchanges increases procurement costs through multiple contracts administration, monitoring many suppliers' performance, continuous education of suppliers on an institution's 
processes and requirements (Mandiyambira, 2012). The issue of institution-supplier relationships have attracted a growing body of academic research in recent times (Terpend et al. 2008). The increased attention reflects the growing awareness of the link between effective management of such relationships and organisations' performance. Effective and efficient management of customer-supplier relationships is crucial because it starts with determining the number and most suitable suppliers for the organisation (Bemelmans, et al., 2011). The resource based view (RBV) provides theoretical support for the significance of collaborations as a solution to exploit complementary capabilities to achieve competitive advantage. It argues that organisations seek to develop competitive advantage through building relationships with key suppliers, having a sound understanding of what the supplier firm can bring to the collaboration (Barney, 1991). The current adversarial relationship between government establishments and suppliers is consistent with Mandiyambira (2012), who argues that most public institutions in Africa adopts procurement systems which are based on adversarial relationships with suppliers. Adversarial relationships do not engender value for money, the core principle governing procurement (Commonwealth Procurement Guidelines, 2005).

Political interference with the procurement process is also a big challenge to the successful implementation of public procurement reforms. A good number of politicians think that they have the right to intervene in the procurement procedures leading to capricious procurement decisions. It is not uncommon in most African countries for politicians to influence the tender process, insisting that particular contracts are awarded to individuals or companies of their choosing (World Bank, 2004).

\section{Improvement Opportunities}

The traditional perception that management is the same or is becoming the same around the world is not tenable in view of the demonstrated differences in national cultures. The debate has intensified in the current era of global operations, as organisations need to know whether management controls that are effective in one national setting will have different levels of effectiveness if used in a different national setting (Chow, Shields, and Wu, 1999). It is significant to acknowledge that many research outputs have shown that national cultural values are related to workplace behaviours, attitudes and other organisational outcomes (e.g., Hofstede, 1980; Trompenaars, 1993). For instance, leadership in a collectivist society in Africa is a group phenomenon. A working group which is not the same as the natural in-group will have to be made into another in-group in order to be effective. In most African countries, foreign management methods and ideas are indiscriminately imposed as part of technology transfer, the majority of which have failed to serve the intended purpose. The evident failure of most international development assistance to developing countries is at least partly due to the lack of cultural sensitivity in the transfer of management ideas (Hofstede, 1983). The myriad challenges militating against the smooth implementation of public procurement reforms in Africa could partly be attributed to the inability of implementing agencies to properly engage beneficiary countries on their cultural, socio-economic, political, ethical, and environmental sensitivities, in order to tailor reforms that suits specific country needs.

A critical examination of most African countries current public procurement laws indicates a prohibition on the use of technology. The situation makes it even more difficult to effectively award contracts and monitor progress of work, but rather encourage bureaucracy and red-tape. With changes in information and communication technology within and between organisations occurring at a fast pace (Zsidisin \& Ellram, 2001), it is imperative that African governments keep pace with modern approaches to information management in order to be competitive. A surge in demand for information dissemination comes with the need for efficient information technology. Institutions are investing in information systems such as, electronic data interchange (EDI), enterprise resource planning (ERP), e-procurement and inter-organisation systems, to enhance communication with stakeholders (Laudon et al, 2002). The application of information systems technology to enhance procurement performance is an important issue that continues to receive managerial and academic attention (Quesada and Gonzalez, 2010). Among the information systems applications, e-procurement functions are particularly important due to the fact that procurement is one of the most critical functions of supply networks (Quesada and Gonzalez, 2010). To this effect, the adoption of e-procurement systems would assist governments to improve transparency and efficiency, reduce cost, enhance better decision-making, improve supplier performance monitoring, and quality of services to customers (Neupane, et al., 2012). The application of procurement technologies mean much of the paper-based routine tasks will be automated. EDI is significant because it eliminates many of the time consuming steps involved in traditional information flow (Humphreys, 2001), hence allowing more time for practitioners to focus on new forms of supplier relationships, supply management, advanced planning and value creating activities (Humphreys et al., 1998; Humphreys, 2001; Croom \& Johnston, 2003; Giunipero et al., 2005).

Business relationships play an important role in enabling firms to respond to dynamic and unpredictable changes occurring in the business environment (Hoyt \& Huq, 2000). Such relationships focus on initiatives that enhance 
superior relational characteristics between business engagements and create a win-win situation for organisations and its suppliers instead of adversarial relationships (Paulraj \& Chen, 2005). Through close relationships with suppliers, organisations are willing to share risk and reward, encourage mutual planning and problem-solving efforts, and maintain the relationships over a longer period of time (Cooper \& Ellram, 1993; Stuart, 1993; Chen et al., 2004; Li et al., 2007). Forging long-term relationships in a competitive business environment helps firms achieve superior performance by reducing cost, improving quality, and enhancing customer responsiveness or flexibility (De Toni et al., 1994). Collaborating across the procurement functions provides opportunities for better utilisation of procurement skills and resources maximise benefits, and the spread of best practice (Mandiyambira, 2012). As firms increasingly emphasise collaborative relationships with key suppliers, buyer institutions are using supplier evaluations to ensure that their performance objectives are met (Prahinski \& Benton, 2004). Evaluating supplier performance is necessary because it affords institutions the opportunity to develop critical product and process categories with key suppliers (Monczka et al., 1993). A good supplier evaluation process would give the buying institution adequate information to determine if the supply base is capable of meeting current and future needs. In some cases buying institutions based on evaluation reports organise supplier development programs with the intention of meeting their current and future business needs by improving supplier performance and capabilities (Prahinski \& Benton, 2004).

\section{Conclusion}

This paper sought to evaluate the impact of procurement reforms on governments in Africa. The authors specifically evaluated the success stories as well as possible challenges impinging upon the smooth implementation of the reforms. The paper further recommends a possible review of current strategies and suggests some improvement strategies that could be of tremendous benefits to the reform process.

Public procurement reforms in Africa have to some extent improved financial management, transparency, and fairness among government agencies in most of the implementing countries. The reform has necessitated the setting-up of new administrative and legal frameworks for dealing with public procurement and other procurement related issues. Institutions and structures have been established to ensure that systems are effectively managed and consolidated. Research has also shown that efforts continue to be made to train and educate practitioners from both public and private organisations on the tenets of the reform in order to render them efficient. Despite the modest successes chalked since the reforms were instituted a little over a decade ago, many countries are still confronted with what one may consider as teething problems such as inadequate qualified personnel, the inability of practitioners to adequately and accurately interpret their countries' respective procurement laws, and the perception of corruption still high. The pressing problem of the lack of political will by politicians to commit fully to the reforms is among the myriad of challenges bedevilling the successful implementation of the reforms.

Some of the challenges identified could be traced to the extent and level of due diligence performed on implementing countries prior to the reform being rolled out. The apparent disregard for national cultures, the neglect of socio-economic, political, ethical, and environmental sensitivities of countries has invariably rendered the reform alien to African governments and people. The lack of or inadequacy of engagements with the people makes the institution and implementation of the reform quite 'reckless', hence the difficulties in surmounting some of the challenges militating against the smooth implementation of the public procurement reforms.

\section{Future Research}

Although corruption or the perception of corruption is high in Africa, the focus of our paper is on the impact of procurement reforms on financial management in Africa, which has nothing to do with corruption. Future research could examine the thorny issue of corruption in public procurement in Africa.

\section{References}

Abeillé, B. (2003). Overview of Procurement Reforms in Africa. Paper presented at the Joint World Trade Organisation/World Bank Regional Workshop on Procurement Reforms. Retrieved from http://www.wto.org

ADB/ OECD. (2008). Fighting Bribery in Public Procurement in Asia and the Pacific. Bali: Secretariat of the ADB/OECD Anti-Corruption Initiative for Asia and the Pacific. http://dx.doi.org/10.1787/9789264046955-en

AfDB. (2009). High-Level Forum Adopts Tunis Declaration on Public Procurement Reforms in Africa. Retrieved from http://www.afdb.org/en/news-and-events/article/high-level-forum-adopts-Tunis-declaration-on-public -procurement-reforms-in-africa

Ahuja, G. (2000). Collaboration networks, structural holes and innovation: A longitudinal study. Administrative Science Quarterly, 45, 425-455. http://dx.doi.org/10.2307/2667105 
Ameyaw, C., Mensah, S., \& Osei-Tutu, E. (2011). Challenges facing the smooth implementation of Ghana's Public Procurement Law, 2003, Act 663. In S. Laryea, R. Leiringer, \& W. Hughes (Eds), Paper presented at the West Africa Built Environment Research (WABER) Conference, Accra, Ghana.

APCC. (2008). Australian procurement and construction council. Retrieved from http://www.apcc.gov.au

Araujo, A. (2004). Procurement capacity building in developing countries a presentation at the international public procurement conference: Fort Lauderdale, Florida, USA.

Barney, J. B. (1991). Firm resources and sustained competitive advantage. Journal of Management, 17, 99-120. http://dx.doi.org/10.1177/014920639101700108

Bemelmans, J., Voordijk, H., Vos, B., \& Buter, J. (2011). Assessing buyer-supplier relationship management: Multiple case studies in the Dutch construction industry. Journal of Construction Engineering and Management, 138(1), 163-176. http://dx.doi.org/10.1061/(ASCE)CO.1943-7862.0000418

Chen, I. J., Paulraj, A., \& Lado, A. A. (2004). Strategic purchasing, supply management, and firm performance. Journal of Operations Management, 22(5), 505-523. http://dx.doi.org/10.1016/j.jom.2004.06.002

Chow, C. W., Shields, M. D., \& Wu, A. (1999). The importance of national culture in the design of and preference for management controls for multi-national operations. Accounting, Organizations and Society, 24(5), 441-461. http://dx.doi.org/10.1016/S0361-3682(99)00047-1

Commonwealth Procurement Guidelines. (2005). Retrieved from http://www.dofa.gov.au/ctc/docs

Cooper, M. C., \& Ellram, L. M. (1993). Characteristics of supply chain management and the implication for purchasing and logistics strategy. International Journal of Logistics Management, 4(2), 13-24. http://dx.doi.org/10.1108/09574099310804957

Cousins, D. P., Lawson, B., \& Squire, B. (2006). An empirical taxonomy of purchasing functions. International Journal of Operations \& Production Management, 26(7), 775-794. http://dx.doi.org/10.1108/01443570610672239

Croom, S., \& Johnston, R. (2003). E-service: Enhancing internal customer service through e-procurement. International Journal of Service Industry Management, 1(5), 539-556. http://dx.doi.org/10.1108/09564230310500219

De Toni, A., Nassimbeni, G., \& Tonchia, S. (1994). New trends in the supply environment. Logistics Information Management, 7(4), 41-51. http://dx.doi.org/10.1108/09576059410066426

Doyle, S. (2006). Evaluating campaign management or MRM vendors: A business view point. The Journal of Database Marketing \& Customer Strategy Management, 14(1), 78-85. http://dx.doi.org/10.1057/palgrave.dbm.3250038

European Commission. (2007). Overview of the implementation of direct payments under the CAP in Member States. Retrieved from http:// ec.europa.eu/ agriculture/ markets/sfp/ ins_en.pdf

Giunipero, C. L., Denslow, D., \& Eltantawy, R. (2005). Purchasing/supply chain management flexibility: Moving to an entrepreneurial skill set. Industrial Marketing Management, 34, 602-613. http://dx.doi.org/10.1016/j.indmarman.2004.11.004

Helgadottir, H. (2008). The ethical dimension of project management. International Journal of Project Management, 26(7), 743-748. http://dx.doi.org/10.1016/j.ijproman.2007.11.002

Hofstede, G. (1980). Culture's consequences: International differences in work-related values. Beverly Hills, CA: Sage.

Hofstede, G. (1983). Cultural Constraints in Management Theories. Academy of Management Executive, 7, 81-94.

Honkaniemi, N. (2010). Conditionality World Bank Crisis-Lending to Ghana. Retrieved from http://www.eurodad.org/uploaded Files/Whats_New/Reports

Hoyt, J., \& Huq, F. (2000). From arms-length to collaborative relationships in the supply chain: An evolutionary process. International Journal of Physical Distribution and Logistics Management, 30(9), 750-764. http://dx.doi.org/10.1108/09600030010351453

Hsu, H. C. (2009). Determining optimal order quantity per procurement cycle with a given length for a consumption part subject to obsolescence phenomenon. 
Humphreys, P. (2001). Designing a management development programme for procurement executives. The Journal of Management Development, 20(7), 604-623. http://dx.doi.org/10.1108/EUM0000000005635

Humphreys, P., Mak, K., \& Yeung, C. (1998). A just-in-time evaluation strategy for international procurement. Supply Chain Management: An International Journal, 3(4), 175-186. http://dx.doi.org/10.1108/13598549810244197

Hunja, R. R. (2003). Obstacles to public procurement reform in developing countries. Public Procurement: The Continuing Revolution, Kluwer Law International.

Kung, D. S., \& Gordon, L. C. (2007). E-transformation: the restructuring of the supply chain of mature business industry via e-technology and strategic IT deployment in the automobile industry. E-Leader Conference, Hong Kong, ISSN 19354800.

Lau, A. K. W. (2010). Training needs of purchasing and supply management personnel in Hong Kong. Journal of European Industrial Training, 34(5), 400-415. http://dx.doi.org/10.1108/03090591011049783

Laudon, K. C., \& Laudon, J. P. (2002). Management information systems: managing the digital firm (7th ed.). NJ: Prentice Hall.

Leenders, J., \& Flynn, F. (2006). Purchasing and Supply Management (13th ed.). New York: McGraw-Hill/Irwin.

Li, W., Humphreys, P. K., Yeung, A. C. L., \& Cheng, E. T. C. (2007). The impact of specific supplier development efforts on buyer competitive advantage: an empirical model. International Journal of Production Economics, 106(1), 230-247. http://dx.doi.org/10.1016/j.ijpe.2006.06.005

Lionjanga, A. V. (2003). Presentation to the Joint WTO-World Bank Regional Workshop on Procurement Reforms and Transparency in Public Procurement for Anglophone African Countries 14-17 January 2003. Dar Es Salaam.

Maister, D. (1986). How to build human capital. The American Lawyer, 6.

Mandiyambira, R. (2012). Managing supplier relationships to improve public procurement performance. African Journal of Business Management, 6(1), 306-312.

Matthew, D. (2005). Strategic Procurement in the Public Sector: A Mask for Financial and Administrative Policy. Journal of Public Procurement, 5(3), 388-399.

Matthew, H. (2010). EU Public Procurement Rules. The International Comparative Legal Guide To Public Procurement 2010. Global Legal Group. Retrieved from http://www.iclg.co.uk/khadmin

Mayring, P. (2008). Qualitative Inhaltanalyse - Grundlagen und Techniken (Qualitative content analysis), Beltz Verlag, Weinheim.

Monczka, R. M., Trent, R. J., \& Callahan, T. J. (1993). Supply base strategies to maximize supplier performance. International Journal of Physical Distribution and Logistics Management, 23(4), 42-54. http://dx.doi.org/10.1108/09600039310041509

Neupane, A., Soar, J., Vaidya, K., \& Yong, J. (2012). Role of public e-procurement technology to reduce corruption in government procurement Paper presented at the Proceedings of the 5th International Public Procurement Conference (IPPC5).

Odhiambo, W., \& Kamau, P. (2003). Public Procurement: Lessons from Kenya, Tanzania and Uganda. OECD Working Paper NO.208. OECD Development Centre.

OECD-DAC/World Bank. (2011). Organization for Economic Committee Development (OECD)/Development Assistance Committee (DAC)/ World Bank, Joint Venture for Procurement. Methodology for Assessment of National Procurement Systems.

Paulraj, A., \& Chen, I. J. (2005). Strategic supply management and dyadic quality performance: A path analytical $\begin{array}{lllll}\text { model. Journal of Supply Chain } & \text { Management, } & \text { 41(3), } & \text { 4-18. }\end{array}$ http://dx.doi.org/10.1111/j.1055-6001.2005.04103002.x

Prahinski, C., \& Benton, W. (2004). Supplier evaluations: communication strategies to improve supplier performance. Journal of Operations Management, 22(1), 39-62. http://dx.doi.org/10.1016/j.jom.2003.12.005

Public Procurement Act, 2003 (Act 663) of the Republic of Ghana. 
Quesada, G., González, M. E., Mueller, J., \& Mueller, R. (2010). Impact of e-procurement on procurement practices and performance. Benchmarking: An International Journal, 17(4), 516-538. http://dx.doi.org/10.1108/14635771011060576

Scott, T. (2008). Procurement: The growth imperative. Government News, 28(9), 31.

Seuring, S., \& Gold, S. (2012). Conducting content-analysis based literature reviews in supply chain management. Supply Chain Management: An International Journal, 17(5), 544-555. http://dx.doi.org/10.1108/13598541211258609

Stuart, F. I. (1993). Supplier partnerships: influencing factors and strategic benefits. International Journal of Purchasing and Materials Management, 22-28.

Terpend, R., Tyler, B. B., Krause, D. R., \& Handfield, R. B. (2008). Buyer-supplier relationships: Derived value over two decades. Journal of Supply Chain Management, 44(2), 28-55. http://dx.doi.org/10.1111/j.1745-493X.2008.00053.x

Thai, K. V. (2008). Measuring losses to public procurement corruption: The Uganda case. Paper presented at the 3rd International Public Procurement Conference Proceedings. http://dx.doi.org/10.1201/9781420054590

Trompenaars, F. (1993). Riding the Waves of Culture: Understanding Cultural Diversity in Business, 6-10. London: Nicholas Brealey.

Wittig, W. (1999). Building value through public procurement: a focus on Africa. International Trade Centre.

Woolcock, S. (2008). Public Procurement and the Economic Partnership Agreements: assessing the potential impact on ACP procurement policies Commonwealth Secretariat.

World Bank. (2003). Ghana 2003 Country Procurement Assessment Report, Washington, DC: Ghana Country Department, The World Bank.

World Bank. (2004). Uganda Country Procurement Assessment Report Vol. II Main Findings and Recommendations. Operational Quality and Knowledge services, African Region.

Zsidisin, A. G., \& Ellram, M. L. (2001). Activities related to purchasing and supply management in supplier alliances. International Journal of Physical Distribution and Logistics Management, 31(9), 629-646. http://dx.doi.org/10.1108/09600030110408143

\section{Copyrights}

Copyright for this article is retained by the author(s), with first publication rights granted to the journal.

This is an open-access article distributed under the terms and conditions of the Creative Commons Attribution license (http://creativecommons.org/licenses/by/3.0/). 